\title{
DETERMINASI EVA, MVA, LIKUIDITAS DAN FIRM SIZE TERHADAP HARGA SAHAM DI PERUSAHAAN RETAIL INDONESIA
}

\author{
Mastor Chris Thover ${ }^{1}$, Purwanto ${ }^{2}$, Dedi Rianto Rahadi ${ }^{3}$ \\ ${ }^{1} J u r u s a n$ Manajemen, Fakultas Bisnis, Universitas Presiden \\ Email: mastorchthoper@gmail.com \\ 2Jurusan Manajemen, Fakultas Bisnis, Universitas Presiden \\ Email: Purwanto@president.ac.id \\ 3Jurusan Manajemen, Fakultas Bisnis, Universitas Presiden \\ Email: dedi1968@president.ac.id
}

\begin{abstract}
ABSTRAK
Tujuan studi ini adalah mengetahui pengaruh economic value added (EVA), market value added (MVA), likuiditas dan firm size terhadap harga saham di industri perdagangan bidang retail. Teknik pengambilan sampel yang digunakan yaitu purposive sampling dengan jumlah sampel sebanyak 12 perusahaan selama periode 2012-2016 di Bursa Efek Indonesia. Data sekunder yang diambil mengacu laporan keuangan yang dipublikasikan secara tahunan. Tahapan prosesnya melalui analisa deskripsi yang meliputi rata-rata, minimum, maksimum dan standar deviasi. Proses selanjutnya uji asumsi klasik yang terdiri dari uji normalitas, heterokedastisitas, multikolinearitas, autokorelasi dan diestimasikan dengan regresi linier berganda. Hasil penelitian menunjukkan bahwa secara parsial variabel EVA, MVA dan firm size berpengaruh positif signifikan terhadap harga saham, sedangkan likuiditas berkontribusi negatif signifikan. Selanjutnya seluruh variabel bebas mempunyai efek signifikan terhadap variabel terikat. EVA memiliki nilai yang paling tinggi perannya dibanding variabel lainnya. Nilai proporsi yang digambarkan dengan koefisien determinasi sebesar $85,6 \%$ dan sisanya $14,4 \%$ yang tidak dijelaskan dalam riset ini.
\end{abstract}

Kata kunci: Economic Value Added, Market Value Added, Likuiditas, Firm Size, Harga Saham

\begin{abstract}
The purpose of this study is to determine the effect of economic value added (EVA), market value added (MVA), liquidity and firm size on stock prices in the retail trade industry. The sampling technique used was purposive sampling with a total sample of 12 companies during the 2012-2016 period on the Indonesia Stock Exchange. Secondary data taken refers to financial statements that are published annually. The stages of the process are through analyzing the description which includes the average, minimum, maximum and standard deviation. The next process is the classic assumption test which consists of tests of normality, heterokedasticity, multicollinearity, autocorrelation and is estimated by multiple linear regression. The results showed that partially EVA, MVA and firm size variables had a significant positive effect on stock prices, while liquidity contributed significantly negatively. Furthermore, all independent variables have a significant effect on the dependent variable. EVA has the highest value of its role compared to other variables. The proportion value represented by the coefficient of determination is $85.6 \%$ and the remaining $14.4 \%$ is not explained in this research.
\end{abstract}

Keywords: Economic Value Added, Market Value Added, Liquidity, Firm Size, Stock Price 


\section{A. PENDAHULUAN}

\section{Latar Belakang Masalah}

Pertumbuhan sektor usaha dan teknologi yang semakin maju merupakan penyebab persaingan bisnis antar organisasi semakin kompetitif baik perusahaan yang memiliki segmen luas maupun lebih kecil. Tak terkecuali perusahaan yang bergerak di industri retail, yang tengah mengalami penurunan pertumbuhan akibat ketatnya persaingan dan perkembangan teknologi yang semakin maju. Manajer perlu memikirkan strategi yang tepat secara matang untuk menghadapi persaingan tersebut, salah mengambil keputusan berakibat fatal bagi organisasi. Baik dan buruknya kinerja akan dijadikan prefernsi bagi pemilik modal, apabila kinerja perusahaan baik menandakan sinyal positif para pengusaha yang akan menanamkan modalnya dengan alasan para investor mempertibangkan bahwa kondisi tersebut layak untuk diinvestasikan. Sebaliknya, apabila kinerja perusahaan buruk, para investor tak akan segan untuk mencabut dananya dari perusahaan tersebut.

Kontribusi pasar modal dalam berperan serta dalam menumbuhkembangkan suatu negara di bidang ekonomi sangat penting karena menyangkut banyak aspek dan sekor yang ada di dalamnya. Salah satu sektornya adalah bidang perdangan di bidang sub sektor pedagang eceran. Salah satu bentuk investasi yang memiliki level risiko yang lebih besar dikomparasikan dengan alternatif investasi lain, seperti obligasi, deposito, dan tabungan adalah pasar modal karena menghasilkan tingkat keuntungan optimal (Dewi, 2015).

Investor yang berbondong bondong menginvestasikan uangnya ke Indonesia menandakan hadirnya pasar modal di Indonesia. Salah satunya adalah para investor yang mulai menginvestasikan sahamnya pada industri perdagangan. Pesatnya perkembangan sektor perdagangan sub sektor pedagang eceran (retail) di Indonesia yang diikuti dengan tingginya permintaan masyarakat terhadap kebutuhan hidup, membuat emiten emiten industri perdagangan membutuhkan dana dari sumber eksternal. Menurut Rachmi (2017), salah satu cara untuk memperoleh dana melalui pasar modal. Perkembangan industri perdagangan dapat dilihat dari gambar dibawah ini:

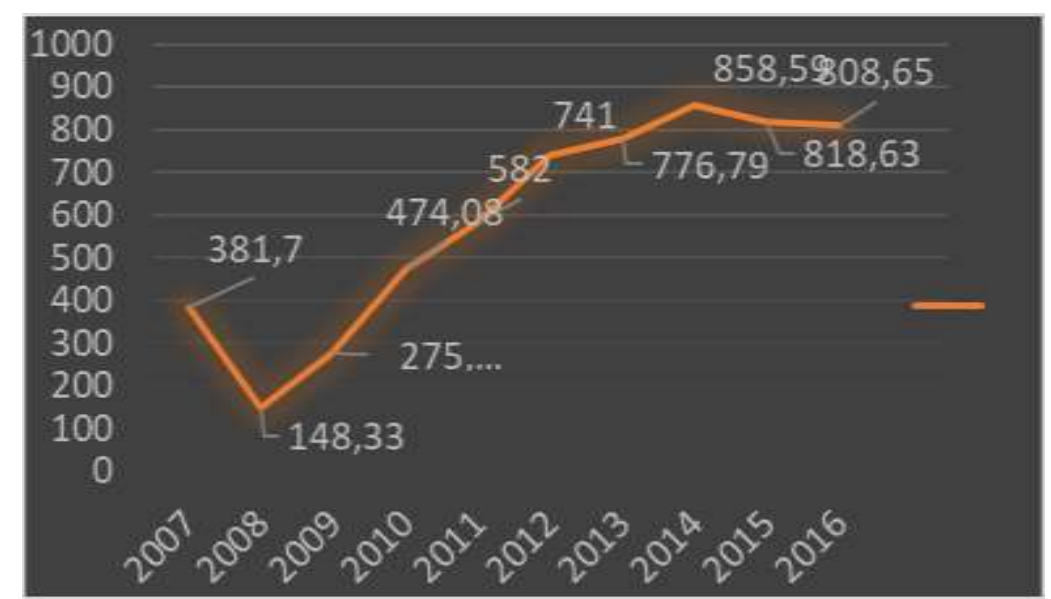

\section{Grafik 1. Pekembangan Indeks Harga Saham Sektor Perdagangan}

Sumber: Otoritas Jasa Keuangan, 2017

Data pada Grafik 1 menunjukkan bahwa dari periode 10 tahun terakhir grafik perkembangan pertumbuhan industri sektor perdagangan mengalami fluaktasi naikturun dengan tren naik. Tahun 2007 ke 2008 mengalami penurunan yang cukup 
signifikan, yaitu dari nilai $\mathrm{Rp} 381,7$ turun menjadi $\mathrm{Rp} 148,33$. Setelah terjadinya penurunan yang cukup drastis pada tahun tersebut, di tahun tahun berikutnya perkembangan pertumbuhan harga saham industri perdagangan mengalami kenaikan secara terus menerus sampai pada tahun 2014 dengan perhitungan angka sebesar Rp 858,59. Kemudian di dua tahun terakhir perkembangan indeks harga saham sektor perdagangan terus mengalami penurunan, yaitu sebesar Rp 818,63 di tahun 2015 dan Rp 808,65 di tahun 2015.

Kesejahteraan pemilik perusahaan diukur dari seberapa tinggi nilai suatu perusahaan miliknya. Harga saham yang di perjualbelikan di bursa mencerminkan nilai suatu perusahaan karena harga saham adalah indikator tinggi atau rendahnya nilai suatu perusahaan. Fokus perusahaan yang berada di pasar modal adalah bagaimana cara untuk menaikkan harga saham perusahaan. Secara teori dapat dikatakan bahwa kinerja perusahaan yang baik menunjukkan meningkatkan nilai pada perusahaan.

Jika organisasi memiliki kemampuan mengkreasikan value yang tinggi, maka ke depannya nilai perusahaan akan terus bertambah dan meningkatkan kesejahteraan para pemegang saham (Febrianti, 2014). Nilai perusahaan yang terus meningkat merupakan bukti bahwa bahwa operasionalisasi mengindikasika berkinerja baik dan memiliki prospek dalam jangka panjang secara lebih baik. Dampak lebih jauh, investor merasa tertarik untuk menanamkan uangnya ke perusahaan karena kepercayaan yang telah dibangun agar menanamkan modalnya di perusahaan yang berkinerja baik akan mendatangkan keuntungan.

EVA adalah analisa kinerja finansial yang menghitung kapabilitas perusahaan dalam menciptakan nilai tambah ekonomi (Shidiq, 2010). Perhitungannya menggunakan laba operasi setelah pajak dikurangi modal yang dipakai untuk mendapatkan profit. Secara sederhana apabila EVA lebih besar daripada 0 (nol) maka perusahaan mampu menciptakan nilai tambah ekonomis, jika nilainya sama dengan 0 (nol) menunjukan posisi impas perusahaan. Sebaliknya, apabila skor lebih kecil daripada 0 (nol) maka hal tersebut menunjukkan bahwa perusahaan belum berhasil memberikan tambahan nilai ekonomis akibat persediaan laba masih terbatas dalam pemenuhan ekspektasi para investor yang menginginkan keuntungan.

MVA adalah akumulasi indikator kinerja finansial yang menggambarkan berapa besarnya tambahan nilai bagi investor dalam menanamkam kapitalnya di dalam perusahaan. Apabila EVA dan MVA bernilai positif, artinya tambahan nilai bagi pemilik modal yang diciptakan perusahaan telah berhasil dilakukan (Ansori, 2015). Hal ini disebabkan kemampuan pengembalian yang didapat melampaui level biaya modal diikuti dengan adanya kenaikan terhadap harga saham. Sebaliknya, apabila keduanya memiliki nilai negatif, maka dapat dikatakan gagalnya perusahaan dalam membuat penambahan nilai karena tingkat pengembalian tidak mampu melampaui biaya modal. yang diikuti dengan turunnya harga saham.

Rasio likuiditas didefinisikan sebagai rasio yang digunakan dalam menginvestigasi kapabilitas suatu organisasi untuk menutupi kewajiban jangka pendek, seperti hutang-hutang jangka pendeknya (Nurul, 2010). Pertimbangan rasio likuiditas dimasukkan dalam penelitian ini karena kalkulasi rasio yang ada dapat melalui modal kerja sebagai sumber informasi, yaitu pos-pos aktiva dan hutang lancar. Karyono (2010) memaparkan laba akan dibagikan secara tunai bagi pemegang saham apabila perusahaan yang memiliki likuiditas baik. Salah satu daya tarik bagi investor karena melihat kemampuan perusahaan memenuhi kewajibannya apakah lancar atau tidak, hal ini terkait dengan risiko yang akan ditanggung saat 
akan menanamkan modalnya. Jika kewajibannya selama ini lancar maka akan menimbulkan efek positif yang akan dapat menarik minat dalam upaya meningkatkan harga sahamnya.

Ukuran perusahaan (firm size) yang bervariasi menjadikan perbedaan penilaian bagi para investor dalam menentukan kemana investor akan menginvestasikan dananya (Ruriana, 2011). Selain analisis rasio, investor memiliki alterrnatif lain dalam berinvestasi, yaitu dengan melihat besar kecilnya perusahaan. Investor cenderung lebih memilih perusahaan dengan ukuran yang lebih besar untuk menanamkan modal mereka. Tata kelola perusahaan berpengaruh positif pada kinerja perusahaan (Mochamad Muslih dan Rianto R, 2019)

\section{Identifikasi Masalah}

Berdasarkan Grafik 1 menunjukkan adanya penurunan perkembangan indeks harga saham sektor perdagangan pada tahun 2015 dan 2016. Hal tersebut mengindikasikan bahwa sektor perdagangan mengalami penurunan performa jika dibandingkan pada tahun-tahun sebelumnya yang selalu mengalami kenaikan. Penilaian kinerja keuangan dalam perusahaan masih jarang memperhatikan nilai tambah terhadap biaya modal yang telah ditanamkan.

\section{Rumusan Masalah} yaitu:

Ditinjau dari latar belakang masalah, penelitian memiliki rumusan masalahan,

1. Apakah ada pengaruh signifikan secara parsial?

a) EVA terhadap harga saham pada perusahaan retail?

b) MVA terhadap harga saham pada perusahaan retail?

c) Likuiditas terhadap harga saham pada perushaan retail?

d) Firm size terhadap harga saham pada perushaan retail?

2. Apakah ada pengaruh signifikan secara simultan EVA, MVA, likuiditas dan firm size terhadap harga sahampada perusahaan retail?

\section{B. TINJAUAN PUSTAKA}

\section{Economic Value Added (EVA)}

EVA merupakan pengukuran keuntungan secara ekonomi dalam suatu organisasi melalui sistem manajemen keuangan. (Widjaja, 2014) menyampaikan tentang kemakmuran yang mampu diciptakan apabila perusahaan dapat mencukupi seluruh operation cost dan cost of capital. Menurut Brigham (2014), menjelaskan EVA sebagai tambahan nilai yang diberikan manajemen kepada pemegang saham. Perusahaan yang memiliki nilai tambah dapat ditandai dengan nilai EVA yang positif. Sebaliknya, EVA dengan nilai negatif menunjukkan perusahaan tersebut tidak mampu menciptakan nilai tambah ekonomis. Metode EVA membuat investor memiliki dasar dalam pengambilan keputusan kemana investor akan menginvestasikan dananya. Asumsinya, pemilik perusahaan akan berupaya semaksimal mungkin dalam menciptakan nilai untuk menarik minat investor.

\section{Market Value Added (MVA)}

Menurut Brigham (2014) segala sesuatu yang telah disediakan oleh investor dan merupakan perbandingan antara nilai pasar saham dan jumlah ekuitas modal. Jika MVA bernilai positif atau bertambah maka perusahaan mampu menciptakan kesejahteraan bagi pemilik modal. Perusahaan yang sudah go-public dapat dilihar harga sahamnya sebagai acuan. MVA adalah tolak ukur yang diterapkan untuk 
menilai kesuksesan perusahaan dalam meningkatkan kekayaan pemegang saham. Didalam metode ini, perusahaan perlu memperhatikan kepentingan dan harapan pemegang modal. Hal ini dapat dinilai dari seberapa tinggi pimpinan perusahan atau manajemen dapat mengalokasikan kesejahteraan kepada para pemegang modal.

\section{Likuiditas}

Perusahaan yang sehat adalah apabila perusahaan mampu menutupi seluruh kewajiban-kewajiban finansial secara tepat waktu. Hal tersebut perlu diperhatikan apabila perusahaan ingin mempertahankan keberlangsungan usahanya. Artinya, perusahaan harus dalam keadaan likuid dalam kondisi apapun. Untuk mengetahui suatu perusahaan likuid atau tidak dapat dilakukan dengan cara menganilis raiso likuiditas. Menurut Brigham dan Houstoun (2014), rasio likuiditas adalah rasio yang memperlihatkan keterkaitan antara aset lancar dan kewajiban lancarnya. Menurut pengertian tersebut, maka dapat dikatakan tentang likuiditas sebagai kapabilitas organisasi agar menutupi tanggung jawab keuangannya pada waktu tertentu. Perusahaan dinyatakan dalam kondisi likuid apabila kewajiban keuangannya mampu dilunasi perusahaan sesuai perjanjian. Rasio yang akan menjadi penelitian ini yaitu menghitung Current Ratio. Dilakukan dengan menghitung komparasi antara aset lancar melalui kewajiban jangka pendeknya.

\section{Current Ratio $=($ Current Aset $) /($ Current Liabilites $) \times 100 \%$}

\section{Ukuran Perusahaan (Firm Size)}

(Lisa dan Jogi, 2013) menyatakan bahwa besarnya ukuran yang dimiliki perusahaan berdampak pada luasnya akses dalam memperoleh sumber pendanaan dari pihak eksternal, serta memudahkan memperoleh pinjaman karena total aset yang besar menjadi jaminan yang terpercaya bagi kreditur atau bank-bank sebagai pemberi pinjaman Sedangkan menurut lbrahim (2008) berpandangan bahwa firm size mengilustrasikan klasifikasi besar kecilnya organisasi melalui ukuran jumlah aktiva, total penjualan, nilai pasar saham yang dimiliki perusahaan.

Pada dasarnya firm size dikategorikan menjadi tiga di antaranya: perusahaan besar, sedang dan kecil. Indikator mengapa suatu perusahaan dapat dikatakan besar, sedang atau kecil dapat ditinjau menurut jumlah aset yang sudah dikumpulkan. Lazimnya, perusahaan besar akan apabila dikomparasikan small company. Adapun cara mengkalkukasi ukuran perusahaan diformulasikan dalam persamaan:

\section{Current Ratio $=($ Current Aset $) /($ Current Liabilites $) \times 100 \%$}

\section{Harga Saham}

Houston dan Brigham (2014) berpendapat bahwa kekayaan pemiliknya (stockholders) akan ditentukan oleh harga saham. Hal ini dapat dijalankan dengan memaksimalkan kekayaan pemegang saham (stockholder wealth maximization) yang diinterpretasikan bagaimana harga saham biasa perusahaan dapat dimaksimalkan. Pendapat Sartono (2008), terbentuknya harga saham karena adanya mekanisme demand dan supply di pasar modal. Jika terjadi dalam kondisi kelebihan permintaan suatu saham, maka kecenderungan harga saham naik. Namun harga saham cenderung turun apabila kelebihan penawaran. 


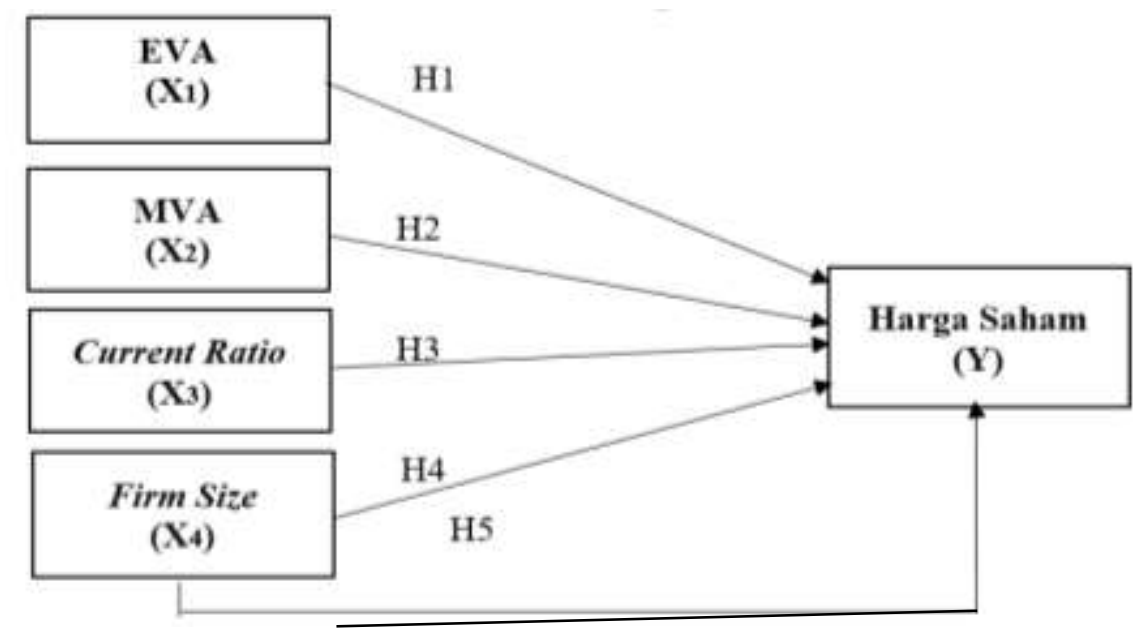

Gambar 2. Kerangka Pemikiran

Sumber: Sumber: Ansori, 2015

\section{Hipotesis}

Hipotesis merupakan asumsi yang bersifat temporer dan akan menjadi jawaban dari sebuah permasalahan dalam investigasi ini. Adapun rumusan hipotesis penelitiannya adalah

$\mathrm{H}_{1}$ : EVA mempunyai pengaruh terhadap harga saham

$\mathrm{H}_{2}$ : MVA berpengaruh terhadap harga saham

$\mathrm{H}_{3}$ : Likuiditas mempunyai pengaruh terhadap harga saham

$\mathrm{H}_{4}$ : Firm Size berpengaruh terhadap harga saham

$\mathrm{H}_{5}$ : EVA, MVA, likuiditas dan firm size secara bersama-sama mempengaruhi harga saham

\section{METODE PENELITIAN \\ Desain Penelitian}

Penelitian ini yang digunakan untuk pengolahan data berupa kuantitatif, yaitu membangun dan mengembangkan pengetahuan dengan angka untuk menerima atau menolak suatu hipotesis (Sekaran dan Bougie, 2011).

\section{Populasi dan Sampel}

Gendro (2011) mengutarakan tentang populasi sebagai suatu daerah atau grup untuk dijadikan subjek generalisasi hasil penelitian yang harus memiliki karakteristik tertentu agar membedakannya dari kelompok subjek lainnya. Keseluruhan observasi yang diambil berfokus pada bagian industri pedagang eceran (ritel) yang berjumlah 23 perusahaan. Menurut Sekaran dan Bougie (2011) proses pemilihan data dari populasi yang dianggap layak dan mewakili penelitian. Adapun pengujiannya dilakukan dengan cara:

\section{Uji T (Parsial)}

Uji ini dianalisis untuk menginvestigasi apakah terdapat efek signifikan bagi variabel bebas secara sendiri-sendiri terhadap variabel terikat. Uji statistik t di sini diterapkan dengan 95\% confidence level, maka $\alpha$ adalah $5 \%=0.05$ dengan hipotesis statistik sebagai berikut:

$\mathrm{H} 01: \beta 1=0$ : Secara parsial EVA tidak mempengaruhi harga saham

Ha1: $\beta 1 \neq 0$ : Secara parsial EVA mempengaruhi harga saham

$\mathrm{H} 02: \beta 2=0$ : Secara parsial MVA tidak mempengaruhi harga saham 
Ha2 : $\beta 2 \neq 0$ : Secara parsial MVA mempengaruhi harga saham

$\mathrm{H} 03: \beta 3=0$ : Secara parsial likuiditas tidak mempengaruhi harga saham

Ha3 : $\beta 3 \neq 0$ : Secara parsial likuidtias mempengaruhi harga saham

$\mathrm{H} 04: \beta 4=0$ : Secara parsial firm size tidak mempengaruhi harga saham

Ha4 : $\beta 4 \neq 0$ : Secara parsial firm size mempengaruhi harga saham

\section{Uji F (Simultan)}

Sarwono (2007) berargumentasi bahwa uji $F$ pada dasarnya menunujukkan apakah keseluruhan variabel bebas berdampak pada variabel terikat atau tidak. Keputusan diambil dengan mempertimbangkan nilai signifikansinya antara lain:

a. Apabila signifikansi $>0,05$, akibatnya menerima $\mathrm{HO}$ dan menolak $\mathrm{H} 1$. Dapat diartikan, seluruh variabel bebas tidak memiliki dampak secara simultan terhadap variabel terikat

b. Jika signifikansi < 0,05, akibatnya H0 ditolak H1 diterima. Dapat diartikan, seluruh variabel bebas mempunyai dampak secara simultan terhadap variabel terikat.

\section{Koefisien Determinasi $\left(R^{2}\right)$}

Koefisien determenasi $\left(R^{2}\right)$ dipakai dalam menyatakan seberapa tinggi kemampuan variabel independen dapat menjelaskan variabel dependen. Angka koefisien determinasi yang lebih dekat satu maka variabel bebas mempengaruhi variabel terikat lebih kuat, tetapi jika koefisien determinasi ke arah nol, artinya kemampuan variabel bebas mempunyai dampak yang lemah terhadap variabel terikat (Ghozali, 2011).

\section{HASIL DAN PEMBAHASAN}

\section{Uji Normalitas}

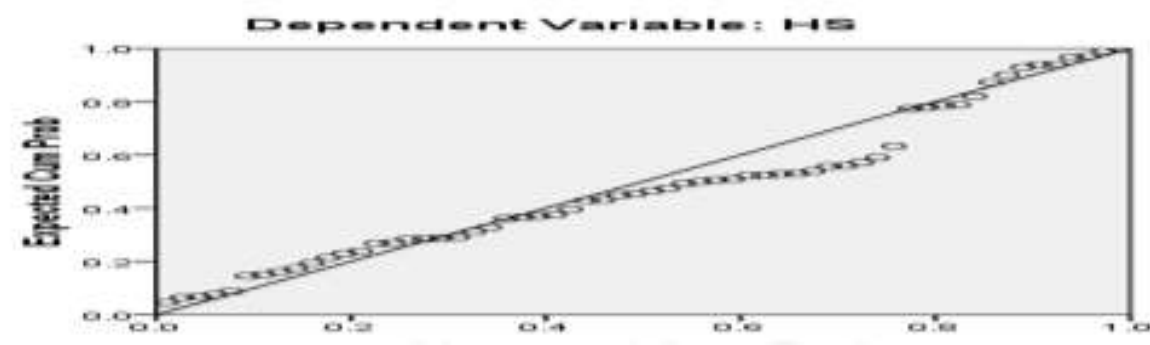

\section{Gambar 3. Normal P-P Plot of Regression Standardized Residual Sumber: Keluaran Program SPSS 16}

Pada ilustrasi di atas memperlihatkan bahwa penyebaran data terletak di dekat garis diagonal serta searah diagonal line. Artinya, data terdistribusi dengan normal serta asumsi normalitas telah terpenuhi dengan model regresi yang memenuhi syarat normalitas.

\section{Uji Heteroskedastisitas}

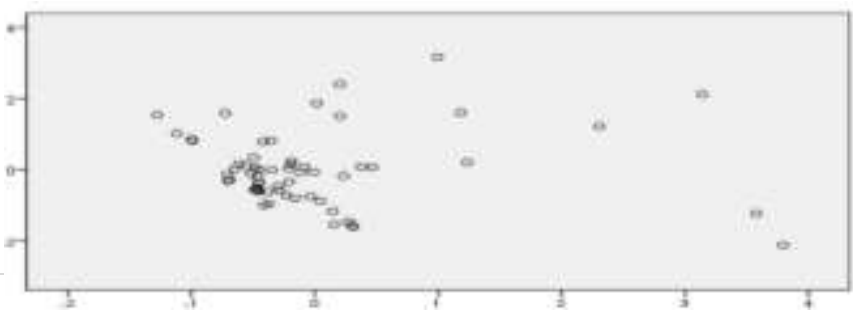




\section{Gambar 4. Hasil Pengujian Heteroskedastisitas Scatter Plot \\ Sumber : Output Program SPSS 16.}

Uji heterokedastisitas pada penelitian ini menggunakan grafik scatterplot. Berdasarkan grafik diatas, model regesi tidak terjadi heterokedastisitas karena sebaran titik-titik secara random dan tidak menggambarkan pola.

\section{Uji Multikolinearitas}

Pada Tabel 1 menggambarkan tolerance value dari setiap variabel bebas serta memiliki nilai melebihi 0,10 dan nilai VIF kurang dari 10. Hal itu membuktikan kalau keempat variabel independen dalam riset ini tidak terjadi hubungan multikolineritas atau tidak ada gangguan multikolinieritas didalam model.

Tabel 1. Hasil Uji Multikolinieritas

\begin{tabular}{|c|c|c|c|}
\hline \multirow{2}{*}{ Model } & \multirow{2}{*}{$\mathrm{N}$} & \multicolumn{2}{|c|}{ Minimum } \\
\cline { 3 - 4 } & & Tolerance & VIF \\
\hline EVA & 60 & 0,714 & 1,400 \\
\hline MVA & 60 & 0,740 & 1,352 \\
\hline CR & 60 & 0,811 & 1,233 \\
\hline FS & 60 & 0,637 & 1,571 \\
\hline
\end{tabular}

Sumber: Output Program SPSS 16

\section{Uji Autokorelasi}

Pengetesan ini diimplementasikan untuk mengidentifikasi apakah dalam riset ini terjadi autokorelasi atau tidak. Teori menyebutkan bahwa nilai dari DW test harus berkisar antara -2 dan +2 untuk mengindikasikan tidak adanya autokorelasi dalam regresi. Hasil dari Durbin-Watson adalah 1,482 yang mengindikasikan bahwa dalam penilitian tidak terdapat autokorelasi karena nilai dari Durbin Watson adalah $-2<$ $1,482<2$.

\section{Analisa Regresi Linier Berganda}

Tabel 2. Keluaran Estimasi Analisis Regresi

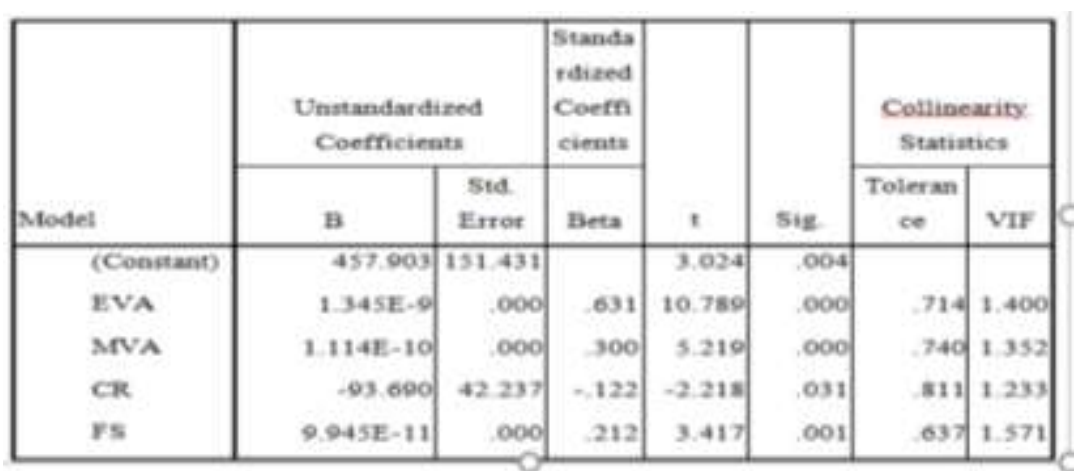

Sumber : Keluaran Program SPSS 16 
Berlandaskan di atas dihasilkan estimasi regresi sebagai berikut:

Harga Saham $=457,903+1,345$ EVA + 1,114 MVA - 93,690 CR + 9, 945 FS

\section{Pengujian Uji Hipotesis}

Tabel 3. Uji T

\begin{tabular}{|r|r|r|r|r|r|}
\hline \multirow{2}{*}{ Model } & \multicolumn{2}{|c|}{$\begin{array}{c}\text { Unstandardized } \\
\text { Coefficients }\end{array}$} & $\begin{array}{c}\text { Standardized } \\
\text { Coefficients }\end{array}$ & \multicolumn{1}{c|}{$\mathrm{t}$} & \multicolumn{1}{c|}{ Sig. } \\
\cline { 2 - 6 } & \multicolumn{1}{c|}{$\mathrm{B}$} & Std. Error & \multicolumn{1}{c|}{ Beta } & & \\
\hline 1 & 457,903 & 151,431 & & 3,024 & 0,004 \\
\hline & $1,345 \mathrm{E}-9$ & 0,000 & 0,631 & 10,789 & 0,000 \\
\hline & $1,114 \mathrm{E}-10$ & 0.000 & 0,300 & 5,219 & 0,000 \\
\hline & $-93,690$ & 42,237 & $-0,122$ & $-2,218$ & 0,031 \\
\hline & $9,945 \mathrm{E}-11$ & 0,000 & 0,212 & 3,417 & 0,001 \\
\hline
\end{tabular}

Sumber: Output Program SPSS 16

Berdasarkan Tabel 3 dapat diterangkan di bawah ini:

a. Economic Value Added

Signifikansi yang dimiliki EVA adalah 0,000 dan mengindikasikan bahwa nilai tersebut kurang dari $\alpha=0,05$ serta nilai koefisien regresi yang bernilai positif sebesar 1,345. Artinya, adanya pengaruh positif signifikan EVA terhadap harga saham pada perusahaan ritel.

\section{b. Market Value Added}

MVA memiliki angka signifikansi senilai 0,000 mengindikasikan bahwa harga tersebut di bawah $\alpha=0,05$ serta koefisien regresi sebesar 1,114 yang memiliki arah positif. Kesimpulan yang dapat di ambil adalah terjadi pengaruh positif signifikan MVA pada perusahaan retail terhadap harga saham.

c. Current Ratio

Current ratio memiliki angka signifikansi senilai 0,031 mengindikasikan bahwa nilai tersebut di bawah $\alpha=0,05$ dan koefisien regresi yang bernilai negatif sebesar -99.690. Kesimpulan yang dapat diambil adalah bahwa efek negatif signifikan current ratio terhadap harga saham pada perusahaan retail.

\section{d. Firm Size}

Firm size memiliki angka signifikansi senilai 0,001 mengindikasikan bahwa nilai tersebut kurang dari $\alpha=0,05$ dan koefisien regresi sebesar 9,945 yang berarah positif. Kesimpulan yang dapat diambil adalah terdapat pengaruh positif signifikan firm size terhadap harga saham pada perusahaan retail. 


\section{Koefisien Determinasi}

Kontribusi secara simultan variabel EVA, MVA, current ratio dan firm size terhadap harga saham sebesar $85,6 \%$, sedangkan sisanya diterangkan faktor lain sebesar $14,4 \%$.

Tabel 4. Koefisien Determinasi

\begin{tabular}{|c|c|c|c|c|c|}
\hline Model & $R$ & $R^{2}$ & Adjusted $R^{2}$ & $\begin{array}{c}\text { Std. Error of } \\
\text { the Estimate }\end{array}$ & $\begin{array}{c}\text { Durbin- } \\
\text { Watson }\end{array}$ \\
\hline 1 & $0,930^{\mathrm{a}}$ & 0,865 & 0,856 & 559,69799 & 1,482 \\
\hline
\end{tabular}

Sumber: Output Program SPSS 16

\section{Pembahasan}

\section{a. Pengaruh Economic Value Added terhadap harga saham}

Koefisien regresi yang dimiliki variabel EVA sebesar 1,345 dan melambangkan arah positif serta nilai signifikansi sebesar 0,000. Besarnya EVA akan memberikan konsekuensi terhadap fluktuasi atau naik turunnya harga saham. Penelitian membuktikan para calon investor dan pemegang saham perlu memperhatikan besar kecilnya nilai suatu perusahaan dalam menginvestasikan dana mereka agar mampu meminimalisir kerugian yang di dapat.

\section{b. Pengaruh Market Value Added terhadap harga saham}

Hasil pengujian pada uji t menunjukkan bahwa variabel MVA memiliki nilai koefisien regresi sebesar 1,114 yang verarah positif dan nilai signifikansi sebesar 0,000 . Hasil penelitian membuktikan bahwa besar kecilnya MVA bepengaruh terhadap harga saham. Nilai MVA yang tinggi dan positif menunjukkan bahwa membaiknya tugas yang telah dilaksanakan manajemen bagi pemilik saham dan mencerminkan bahwa manajemen perusahaan berhasil memaksimumkan kekayaan pemegang saham perusahaan.

\section{c. Pengaruh Current Ratio terhadap harga saham}

Hasil pengujian pada uji $\mathrm{t}$ memperlihatkan bahwa variabel current ratio memiliki nilai koefisien regresi sebesar -99,690 yang berarah negatif dan nilai signifikansi sebesar 0,031 . Rendahnya nilai current ratio menunjukkan likuidasi terjadi masalah, sedangkan nilai yang tinggi menandakan dana yang menganggur masih banyak sehingga pada akhirnya dapat mengurangi kemampuan laba perusahaan (Sawir, 2009).

\section{d. Pengaruh Firm Size terhadap harga saham}

Koefisien regresi variabel firm size sebesar 9,945 dengan arah positif dan nilai signifikansi sebesar 0,001 . Salah satu acuan bagi investor dalam memutuskan untuk berinvestasi adalah ukuran perusahaan. Perusahaan dengan ukuran yang besar (big cap) cenderung akan dipilih investor untuk menanamkan dananya disana. Ukuran perusahaan yang besar tentu memiliki jumlah aset yang besar.

\section{e. Pengaruh secara Simultan}

Hasil uji $F$ menunjukkan seluruh variabel independen secara bersamasama mempunyai nilai sebesar 0,000 yang menandakan bahwa pengaruhnya terhadap harga saham sangat tinggi. EVA, MVA, current ratio dan firm size 
menghasilkan angka determinasi 0,856 atau $85,6 \%$ sementara sisanya sebesar $14,4 \%$ yang tidak termasuk dalam faktor ini.

\section{E. SIMPULAN DAN SARAN}

a) EVA memiliki kontribusi terhadap harga saham secara signifikan dengan arah positif. Nilai yang didapat membuktikan adanya kenaikan angka EVA pada perusahaan berjalan seiringan dengan kenaikan harga saham. Sebaliknya, apabila nilai EVA mengalami penurun pada perusahaan, maka terjadi penurunan pada harga saham.

b) MVA mempunyai peranan positif yang cukup besar terhadap harga saham. Besarnya angka MVA pada suatu perusahaan sejalan lurus dengan kenaikan harga saham pada perusahaan dan harus selalu dijaga.

c) Current Ratio bertanda negatif signifikan terhadap harga saham. Hal ini menjelaskan tentang current asset of company yang dinilai investor tidak memiliki efektivitas dalam proses operasional perusahaan dan hasil ini mungkin menurunkan profit yang didapatkan perusahaan.

d) Kondisi harga saham juga dipengaruhi besarnya firm size. Ukuran perusahaan yang besar menandakan bahwa perusahaan cenderung lebih stabil dan mampu menciptakan lebih banyak profit. Hal ini mengindikasikan bahwa besar kecilnya suatu perusahaan mempengaruhi besar kecilnya harga saham.

e) Secara bersama-sama nilai EVA, MVA, current ratio dan firm size memberikan proporsi yang sangat besar terhadap harga saham, yaitu sebesar 85,6\%, selebihnya masih ada sekitar $14,4 \%$ yang dijelaskan oleh faktor lain di luar penelitian ini.

\section{REFERENSI}

\section{Buku}

Brigham, Eugenne \& Houston (2014). Dasar-Dasar Manajamen Keuangan: Essentials of Financial Management. Jakarta: Salemba Empat.

Gendro, W. (2011). Merancang Penelitian Bisnis dengan Alat Analisis SPSS. Yogyakarta: Percetakan STIM YKPM.

Ghozali, I. (2011). Aplikasi Analisis Multivariate dengan Program SPSS. Semarang: Badan Penerbit Dipenegoro.

Karyono. (2010), Forensic Fraud. Yogyakarta: Andi

Sartono, S. (2008). Manajemen Keuangan Teori dan Aplikasi. Yogyakarta: BPFE.

Sarwono, J. (2007). Metode Penelitian Kuantitatif dan Kualitatif. Yogyakarta: Graha IImu.

Sawir, A. (2009). Analisis Kinerja Keuangan dan Perencanaan Keuangan Perusahaan. Jakarta.

Sekaran, U. \& Bougie. (2011). Research Method for Business. Great Britain: Wiley. 


\section{Jurnal}

Ansori. (2015). Pengaruh Economic Value Added dan Market Value Added terhadap Return Saham pada Perusahaan Manufaktur yang Terdaftar di Bursa Efek Indonesia. Yogyakarta: Universitas Negeri Yogyakarta.

Faizah, Nurul. (2010). Analisis Pengaruh Rasio Likuiditas, Profitabilitas, Aktivitas, Leverage dan Firm Size Terhadap Return Saham. Jakarta: Universitas Islam Negeri Syarif Hidayatullah Jakarta.

Fatin, Rachmi. (2017). Pengaruh Economic Value Added (EVA), Market Value Added (MVA), Kebijakan Dividen, dan Beta Pasar terhadap Return Saham pada Perusahaan Manufaktur yang Terdaftar di Bursa Efek Indonesia Periode 2011-2015. Yogyakarta: Universitas Negeri Yogyakarta.

Ibrahim (2008), Pengaruh Tingkat Suku Bunga, Peringkat Obligasi, Ukuran Perusahaan dan DER terhadap Yield to Maturity Obligasi Korporasi di Bursa Efek Indonesia Periode Tahun 2004 -2006, Thesis: Magister Manajemen Universitas Diponegoro

Lisa Puspitasari Sugiono dan Y. Jogi Christiawan (2013), Analisa Faktor yang Mempengaruhi Likuiditas Pada Industri Ritel yang Terdaftar pada Bursa Efek Indonesia Tahun 2007-2012, Business Accounting Review, Vol.1, No. 2, 2013

Mochamad Muslih \& Dedi Rianto Rahadi, Tata Kelola Berkelanjutan Bagi Bumn Bidang Keuangan Non Publik, Firm Journal of Management Studies, Vol. 4 No. 2

Ulfa, Ruriana. (2011). Pengaruh Ukuran Perusahaan, Leverage, Economic Value Added, Return on Investment dan Earning per Share terhadap Return yang Diterima Pemegang Saham. Jakarta.

Wahyuni, Febrianti. (2014). Pengaruh Economic Value Added (EVA), Earning Per Share (EPS), Return on Asset (ROA) dan Ukuran Perusahaan terhadap Harga Saham. Jakarta.

Wijaya, R. A. (2014). Penerapan Konsep Economic Value Added sebagai Alat Ukur Kinerja Keuangan pada CV. Muara Karya Padang. Padang.

Zakia, Dewi. (2015). Analisis Faktor-Faktor yang Mempengaruhi Penciptaan Nilai Bagi Pemegang Saham. feb.unila.ac.id 